\title{
USE OF BOTULINUM TOXIN A AND SUBSEQUENT REHABILITATION IN AMBULATORY CHILDREN WITH SPASTIC CEREBRAL PALSY - EFFECTS AND DILEMMAS
}

\author{
Hristina Čolović1, ${ }^{2}$, Vesna Živković1,2, Dragan Zlatanović1,2, Nadica Milošević-Milenović3, \\ Dragana Janošević-Radovićt,
}

\begin{abstract}
The definition of cerebral palsy (CP) includes a group of permanent developmental disorders of movement and posture that cause activity limitation due to non-progressive lesions in the developing fetal or newborn infant brain. The most common type of CP is spastic cerebral palsy (SCP). One of the primary aims in treating children with SCP is to enable them to perform functional activities, to stimulate effective movement, to prevent deformities of bone and joint system, and to reduce pain. Limb deformities are the most prominent manifestation in children with SCP, greatly preventing them from performing activities of daily living. The reduction of spasticity and prevention of contractures, the development of performing functional activities in the full potential, as well as delays in performing surgical intervention, have dramatically increased the use of botulinum toxin type A (BTA) in treating children with CP lately. It is known as the most potent neurotoxin found in nature that reduces spasticity after application and results in irreversible denervation at the neuromuscular junction, while functional recovery is time limited. In that time period it is necessary to evaluate the functional motor status of a child, clearly and realistically define aims in cooperation with parents, and apply adequate rehabilitation protocol. The international consensus statement in 2010 defined the protocol, dosage, the site of application, and rehabilitation protocol. After being used for two and a half decades, certain dilemmas arose, particularly those regarding rehabilitation effects after BTA application.
\end{abstract}

Acta Medica Medianae 2020;59(1):110-115.

Key words: cerebral palsy, children, botulinum toxin type $A$, spasticity, rehabilitation

\footnotetext{
${ }^{1}$ University of Niš, Faculty of Medicine, Department of Physical Medicine and Rehabilitation, Niš, Serbia

${ }^{2}$ Physical Medicine and Rehabilitation Clinic, Clinical Center Niš, Serbia

${ }^{3}$ Health Center "Hipokrat Group" Niš, Serbia

"University of Niš, Faculty of Medicine, Department of

Obstetrics and Gynecology, Niš, Serbia

${ }^{5} \mathrm{Clinic}$ of Obstetrics and Gynecology, Clinical center Niš, Serbia
}

Contact: Hristina Čolović

17/34 Branka Krsmanovića St., 18000 Niš, Serbia

E-mail: hristinamc@yahoo.com,

hristina.colovic@medfak.ni.ac.rs

\section{Introduction}

Cerebral palsy (CP) is a movement disorder produced by an injury to the immature brain. $\mathrm{CP}$ may be regarded as a static brain lesion causing a permanent motor impairment with evolving musculoskeletal manifestations. A broad spectrum of etiologies mediates neonatal brain injury in preterm and term infants. The most common cause can be cerebrovascular injury. Other etiologies includes: trauma, infections, metabolic dysfunction, etc. CP is the most common movement disorder in children. It occurs in about $1-3$ per 1,000 live births (1). Signs and symptoms appear during infancy or preschool years and can vary greatly. In general, CP causes impaired movement associated with abnormal reflexes, floppiness or rigidity of the limbs and trunk, abnormal posture, involuntary movements, unsteady walking, or some combination of these. Children with $\mathrm{CP}$ also may suffer reduced range of motion at various joints of their bodies due to muscle stiffness (2). Spastic CP (SCP) is the most common type of CP. Up to $80 \%$ of all individuals with CP suffer from some degree of spasticity. The degree of spasticity can vary from mild muscle stiffness to severe, painful, and uncontrollable muscle spasms $(3,4)$. In a person with $\mathrm{CP}$ there is the damage in the brain which is usually in the area of the brain that controls muscle tone and movement of limbs. 


\section{The neural control of movement}

The only action a human can bring about is muscular contraction. This muscular contraction results in movements that may in turn produce walking, writing or speech. But, the first step in performing any action is a thought which emerges in certain areas of the brain, which stimulate cortical motor centers via their connections. So, before an action is made it has been recorded as an electrical potential known as the "readiness potential", and it is located in the supplementary motor area, just anterior to the motor strip. This readiness potential occurs up to one second prior to a voluntary movement, whether the movement occurs in the hand, toe, mouth, tongue or eye, and irrespective of whether the movements are complex and programmed, or simple. Large, fast-firing neurons in the cortex, which are known as Betz cells, contribute axons to motor tracts which descend from the cortex to the brainstem (corticobulbar fibres) and spinal cord (corticospinal tracts) to connect with motor nerves that innervate muscles. The muscles, when stimulated by these motor tracts, then contract to bring about the desired purposeful movement and action (5).

\section{Spasicity and musculoskeletal problems}

Spasticity is one of the major problems in patients who have an upper motor lesion in the brain or spinal cord. The clinical feature of spasticity is increased muscle tone evidenced by a velocitydependent increase in resistance to passive movement. Due to spasticity, the muscle growth in a child with CP will be abnormal for the following reasons: A spastic muscle will not allow stretch to the same degree as one with normal tone, as a result a muscle that initially has dynamic contracture, will soon develop static contracture. Bone growth in CP child is likely to be abnormal. The best example is femoral anteversion. A child with CP typically stands and walks with hips and knees in some flexion. Deformities of the feet are the most common musculoskeletal problem in children with CP. The most common deformity is equinus, which is present in the large majority of children with $\mathrm{CP}$ at the beginning of standing and walking. Children with SCP and equinus gait have longer-than-normal Achilles tendons and shorter-than-normal muscle bellies (6). Spasticity can affect the entire body, but it is generally worse in the lower limbs of children with bilateral involvement and in the upper limbs of children with unilateral involvement (7). Spasticity of the trunk muscles can cause postural problems while spasticity of bulbar origin can result in difficulty in feeding and communication (8). The most commonly affected lower limb muscles in children with SCP are gastroc-soleus, hamstrings, rectus femoris, adductors, and psoas. In the upper limb, spasticity is most frequently found in the shoulder external rotators, elbow, wrist and finger flexors, and the elbow pronators (9). Spasticity is thought to interfere with voluntary control and to increase energy consumption during movement (10). A child who is trying to walk with impaired motor control as well as dynamic and structural musculoskeletal deformities does not have an easy task, and he or she must learn to cope with the resultant problems. Pathological gait is a mixture of many abnormalities.

\section{Management of spasticity in $\mathbf{c p}$}

The treatment includes functional therapies (physiotherapy, occupational therapy, speech therapy, constraint-induced movement therapy, roboticassisted therapy, etc.); injections of botulinum toxin A (BTA); orthoses, casting and splinting; pharmacotherapies; intrathecal baclofen; selective dorsal rhizotomy (SDR); and single-event multi-level orthopaedic surgery, including the minimal invasive and other surgical reconstructive techniques (11). CP rehabilitation programs for children utilize a multidisciplinary approach where members of a team are selected with respect to a child's age, developmental level, severity of impairment, and availability of services. Management of spasticity in CP involves multidisciplinary intervention intended to increase functionality, sustain health, and improve quality of life for children and their carers. Several methods have been developed to assess the degree of spasticity and success of the treatment. The most commonly used tests in clinical practice are the MASModified Ashworth scale and Modified Tardieu scale (12).

A priority in selecting rehabilitation protocol should be arranged as individual therapy approach. By analyzing up-to-date literature data it can be concluded that the most common and comprehensive parts of each treatment are physiotherapy and occupational therapy, with greatly expanding BTA application aiming at avoiding or delaying surgical intervention.

\section{Botulinum Toxin Type A (BTA) and Rehabilitation}

BTA is a neurotoxic protein produced by the bacterium Clostridium botulinum and related species. It prevents the release of the neurotransmitter acetylcholine from axon endings at the neuromuscular junction and thus causes flaccid paralysis. There are eight types of botulinum toxin, named type $\mathrm{A}-\mathrm{H}$. Injections of BTA are recommended for isolated (focal) spasticity. The effects of BTA last for approximately three-four months as the muscle will recover via proximal axonal sprouting, the formation of new neuromuscular junctions, and the regeneration of the original neuromuscular junctions. BTA is considered a safe and effective therapy for children with $\mathrm{CP}$, especially in the hands of experienced injectors and for the majority of children. Over the past two decades BTA has been established as an important treatment modality for spastic movement disorders in children with CP. In most countries worldwide, it is licensed for children older than two years. Recommendations for treatment with BTA have been published since 1993, with continuous optimization and development of new treatment concepts. This leads to modifications in the clinical decision making process, indications, injection techniques, assessments, and evaluations. BTA is an important part of 
multimodal management, to support motor development and improve function when the targeted management of spasticity in specific muscle groups is clinically indicated. Individualized assessment and treatment are essential, and should be part of an integrated approach chosen to support the achievement of motor milestones. To this end, goals should be set for both the long term and for each injection cycle. The correct choice of target muscles is also important; not all spastic muscles need to be injected. A more focused approach needs to be established to improve function and motor development, and to prevent adverse compensations and contractures. The conclusion is that there is no uniform BTA treatment strategy in SCP (11). The main reason is primarily the diversity of clinical manifestations in children with SCP.

Extensive usage and long-term application of BTA in treating spasticity in children with CP have caused a lot of dilemmas, revised certain attitudes and opened a lot of questions. Some very important current dilemmas are those regarding the importance of rehabilitation after BTA application to the lower extremity spastic muscle in ambulatory children, as well as measurements and comparison of individual contribution of these two treatments. Functional tests have an important role in monitoring and evaluating the success of treatment outcomes. Most commonly used ones include Gross Motor Function Classification System (GMFCS) for the estimation of achieved functional motoric level of evaluated patients-the classification system for the estimation of adopted rough motoric functions in children with CP (13), and Gross Motor Function Measure (GMFM) score to measure the change in gross motor function during the follow-up of evaluated patients with CP we used (14).

BTA is licensed for use in the management of spasticity in children aged 2 years or over, so the majority of studies lack outcome effects in younger children (15). In ambulant children with SFCP, gait disturbances are evident at the age of two. During the period of abrupt growth period fixed contractures develop rapidly, as well as the resulting deformities. Besides the aforementioned, the recommendation of the Surveillance of Cerebral Palsy in Europe (SCPE) is that definitive diagnosis of CP should not be established until the age of 3 years, when motor impairment is evident (2).

Currently, application of BTA treatment in children under the age of two is being debated. By analyzing the results from 3 randomized trials, with the youngest participant aged 11 months, it has been demonstrated that BTA application resulted in reducing spasticity, preventing contractures, and postponing surgery interventions. But, there is no evidence regarding the improvement in general motor development. Further studies are needed to further the knowledge, as well as the development of reliable assessment tools for such young infants. It is important to point out that two studies included a rehabilitation modality as a part of compulsory therapeutic treatment after application of BTA, such as stretching program and occupational therapy (16).
The safety profile of the recommended doses of BTA is the same for children under two years as for older children (17).

According to the last international consensus from 2010, it is recommended to apply individualized rehabilitation approach encompassing physiotherapy (especially stretching and strengthening) and occupational therapy, after BTA treatment of lower limbs in children with SCP. The recommendations are based on the result of papers published up to 2010, stating that the aforementioned therapy combined with BTA therapy is more beneficial than occupational and physiotherapy alone (18), and is recommended in patients receiving BTA therapy (19). The authors recommend precise measurements of qualitative and quantitative data in order to obtain high quality assessment of the outcomes. Considering the fact that there is no measurement unit encompassing both values, it is recommended that outcome measures should include at least one objective measurement on limb mobility related to local response to BTA application, as well as at least one measurement of functional outcome and treatment satisfaction. There are numerous tests prepared for children, but the first recommendation states that in ambulatory children with $\mathrm{CP}$, PRS (Physician Rating Scale for Gait Analysis) is used to describe the quality of gate. In clinical practice, description and function of gait are relevant not only in monitoring therapy effects, but also in selecting target muscles and possible orthotic applications. The gold standard for the comprehensive assessment of gait function in ambulant children with $\mathrm{CP}$ is 3-dimensional gait analysis (3DGA), but it is not available at all levels of the health-care system. Besides the aforementioned, it is also not applicable in many children with best results achieved by BTA treatment, aged from one to four years, children with restricted walking ability (GMFMC levels I-III), due to difficulties in cooperation with children and inadequate physical measurements for obtaining a complete 3DGA analysis. 3DGA is complex, expensive, not always available, thus being impractical for routine practice. Because of that, simplified methods of gait analysis have been developed for spastic cerebral palsy, using standardized scoring system from video recordings. In the absence of 3DGA, utilization of modified PRS is recommended for gait analysis by the International Committee for BTA treatment (19).

Kinesiotherapy and occupational therapy are not the only modalities of rehabilitation protocol after BTA application; they may include hydro- and thermotherapy along with orthotic applications, based on physician's assessment. The authors of this paper investigated the effects of BTA injection and the effects of rehabilitation on spastic equinus correction. The youngest participant was 2 years and 9 months old, and the oldest was 6 years old. Rehabilitation protocol included: physical therapy individually designed, including thermotherapy; kinesiotherapy (exercises included movement range increase, ankle dorsiflexion facilitation, muscle stretching, antagonists strengthening, gait training, coordination, and correction of acquired improper 
motor functions); occupational and functional therapy, and prescription of adequate orthoses for deformity correction. The program was initiated 5 days after BTA-ABO application, with the plan of the standardized physical therapy to be performed 3 times weekly in duration of $1 \mathrm{~h}$ per child. In the literature, such a plan implies intensive physical therapy (IPT). For the purpose of this study the physical therapy program lasted for 16 weeks. The values of passive foot dorsiflexion after 6 months, even though they were close to the initial values, were still highly significantly different $(p<0.05)$. After 6 months there was non-significant change in the proportion of patients regarding spasticity levels, even though a distribution trend of lower spasticity levels was noticed. Mean values of GMFM-D score (motor functions related to abilities of standing up and standing) after $3,8,16$ weeks, as well as after 6 months, statistically significantly differ (higher values) versus the initial value before treatment (20).

In children with SFCP gait disorders, BTA application in lower limbs was followed by iPT ( 3 times weekly, 45-60 min duration per child, during a 16week period). By the protocol, after BTA application (5-7 days), the rehabilitation programme included paraffin therapy, kinesiotherapy (exercises to increase movement range, elongation of muscles with reduced length, strengthening of the antagonists, balance and coordination exercises, exercises for the correction of improperly developed motoric functions: sitting, crawling, walking and for the stimulation of non-developed motor functions), occupational and functional therapy and application of adequate orthoses for the correction of foot equinus deformity. The effects of the therapy were assessed by monitoring functional motor status, using the motor function standardization system in children with $\mathrm{CP}$ (GMFCS), by quantification of adopted motor functions (GMFM-88), and by spasticity measurements as well. It has been noticed that children with $\mathrm{CP}$ achieve a higher level of motor development through BTA treatment and IPT, they benefit from this development for longer than they would solely from the pharmacological effect of BTA (21).

The analysis of the protocol stating that it is necessary to conduct rehabilitation treatment after BTA application into the spastic musculature of lower limbs gives rise to the question on the contribution of each separate treatment. Although it is well known from scientific literature that such combinations are more effective than sporadic physical therapy, the contribution of expensive BTA injections in overall treatment effect is unknown. Schasfoort et al. (2018) (22) published a study in 2018 to determine the effectiveness of BTA treatment prior to intensive physiotherapy (iPT) in comparison to iPT alone in a group of 65 children with SCP, aged between 4 and 12 years. The effectiveness of the treatment was monitored by the measurements of the following parameters: leg muscle strength, muscle length and spasticity of several leg muscles, CP-related pain, walking speed, several gait parameters, the degree of achieved individually tailored therapeutic goals and general functioning reported by parents. The results showed no differences between the groups. This suggests that extensive prescribing and utilization of BTA in ambulatory children with SFCP in this age group requires critical reconsideration. The authors of the study do not question the working mechanism or efficacy of BTA, but they demonstrate the possibility of false indications for BTA treatment, although the medical specialists included in the study had enough experience with BTA. A possible answer is that clinical assessment of spasticity is a subjective method representing a response to passive muscle stretching. The assessment is complicated because it is difficult to make a reliable distinction between non-neural (tissue-related) and neural (central nervous system related) contributions to hyper-resistance (23). That is why future studies should employ instrumented/quantitative assessment of different components of hyper-resistance aiming at precisely defining indications and categories of patients who require BTA treatment. Unlike BTA treatment, the results revealed unquestionable effect of iPT in both groups. Of course, a revised international consensus is needed to determine time periods for intensive rehabilitation.

\section{Conclusion}

The treatment of lower limbs spasticity in ambulatory children with SFCP requires a multidisciplinary approach, primarily employing rehabilitation and BTA application.

However, despite widespread use of BTA, its role prior to period of iPT with orthoses utilization remains unclear. Critical evaluation of literature data on effectiveness of BTA shows that the conclusions have been made on implicated assumption that BTA is the most effective component of the combined modalities for spasticity treatment. For this reason, positive clinical experience in combining BTA and other therapies may unjustly be attributed to BTA injections. In current papers that compared contribution of BTA and iPT, iPT is undoubtedly the dominant component for effectiveness. Of course, the effectiveness of BTA in spasticity treatment is unquestionable; however, it is necessary to define the subgroup of children with gait impairment that is most likely to benefit from BTA treatment. 


\section{References}

1. Rosenbaum P, Rosenbloom L. Cerebral palsy: from diagnosis to adult life. Dorchester: Mac Keith Press; 2012.

2. Prevalence and characteristics of children with cerebral palsy in Europe. Dev Med Child Neurol 2002;44(9): 633-40. [CrossRef] [PubMed]

3. Ramstad $\mathrm{K}$, Jahnsen $\mathrm{R}$, Skjeldal $\mathrm{OH}$, Diseth $\mathrm{TH}$. Characteristics of recurrent musculoskeletal pain in children with cerebral palsy aged 8 to 18 years. Dev Med Child Neurol 2011;53(11):1013-8.

[CrossRef] [PubMed]

4. Parkinson KN, Dickinson HO, Arnaud C, Lyons A, Colver A; SPARCLE group. Pain in young people aged 13 to 17 years with cerebral palsy: cross-sectional, multicentre European study. Arch Dis Child 2013;98 (6):434-40. [CrossRef] [PubMed]

5. Crossman AR, Neary D. Neuroanatomy: an illustrated colour text. $3^{\text {rd }}$ edition. Edinburgh, New York: Elsevier; 2005.

6. Bar-On L, Molenaers G, Aertbelien E, Van Campenhout A, Feys $H$, Nuttin B, et al. Spasticity and its contribution to hypertonia in cerebral palsy. Biomed Res Int 2015; 2015:317047. [CrossRef] [PubMed]

7. Sakzewski L, Ziviani J, Boyd R. Systematic review and meta-analysis of therapeutic management of upperlimb dysfunction in children with congenital hemiplegia. Pediatrics 2009;123(6):e1111-22. [CrossRef] [PubMed]

8. Barnes MP, Johnson GR, editors. Upper Motor Neurone Syndrome and Spasticity. Clinical Management and Neurophysiology. $2^{\text {nd }}$ edition. Cambridge, UK: Cambridge University Press; 2008. [CrossRef]

9. Klingels $K$, Demeyere $I$, Jaspers $E$, De Cock $P$, Molenaers $G$, Boyd $R$, et al. Upper limb impairments and their impact on activity measures in children with unilateral cerebral palsy. Eur J Paediatr Neurol 2012; 16(5):475-84. [CrossRef] [PubMed]

10. Gage JR, Schwartz MH, Koop SE, Novacheck TF. The identification and treatment of gait problems in cerebral palsy. Dorchester: Mac Keith Press; 2009.

11. Strobl W, Theologis T, Brunner R, Kocer S, Viehweger E, Pascual-Pascual I, et al. Best clinical practice in botulinum toxin treatment for children with cerebral palsy. Toxins (Basel) 2015;7(5):1629-48. [CrossRef] [PubMed]

12. Alhusaini AA, Dean CM, Crosbie J, Shepherd RB, Lewis J. Evaluation of spasticity in children with cerebral palsy using Ashworth and Tardieu scales compared with laboratory measures. J Child Neurol 2010;25 (10):1242-7. [CrossRef] [PubMed]

13. Rosenbaum PL, Palisano RJ, Bartlett DJ, Galuppi BE, Russell DJ. Development of the gross motor function classification system for cerebral palsy. Dev Med Child Neurol 2008; 50(4):249-53. [CrossRef] [PubMed]

14. Lundkvist Josenby A, Jarnlo GB, Gummesson C, Nordmark E. Longitudinal construct validity of the
GMFM-88 total score and goal total score and the GMFM-66 score in a 5-year follow-up study. Phys Ther 2009;89(4):342-50. [CrossRef] [PubMed]

15. Allergan. Global in Reach. Specialed in Focus. Available from: URL: http://www.allergan.com Internet article in electronic format: Morse SS. Factors in the emergence of infectious diseases. Emerg Infect Dis (serial online) 1995 Jan-Mar "cited 1996 Jun 5"; 1(1)(24 screens). Available from: URL: http://www.cdc.gov/ncidod/EID/eid.htm

16. Druschel C, Althuizes HC, Funk JF, Placzek R. Off label use of botulinum toxin in children under two years of age: a systematic review. Toxins (Basel) 2013; 5(1): 60-72. [CrossRef] [PubMed]

17. Pascual-Pascual SI, Pascual-Castroviejo I. Safety of botulinum toxin type $A$ in children younger than 2 years. Eur J Paediatr Neurol 2009; 13(6):511-5. [CrossRef] [PubMed]

18. Kanovsky P, Bares M, Severa S, Richardson A. Longterm efficacy and tolerability of 4-monthly versus yearly botulinum toxin type $A$ treatment for lower-limb spasticity in children with cerebral palsy. Dev Med Child Neurol 2009; 51(6):436-45. [CrossRef] [PubMed]

19. Love SC, Novak I, Kentish M, Desloovere K, Heinen F, Molenaers G, et al. Botulinum toxin assessment, intervention and after-care for lower limb spasticity in children with cerebral palsy: International consensus statement. Eur J Neurol 2010;17(Suppl 2):9-37. [CrossRef] [PubMed]

20. Čolović H, Dimitrijević L, Stanković I, Nikolić D, Radović-Janošević D, Živanović $D$. The effects of botulinum toxin type a on improvement and dynamic spastic equinus correction in children with cerebral palsy- preliminary results. Arch Med Sci 2014; 10(5): 979-84. [CrossRef] [PubMed]

21. Čolović H, Dimitrijević L, Stanković I, Nikolić D, Radović-Janošević D. Estimation of botulinum toxin type A efficacy on spasticity and functional outcome in children with spastic cerebral palsy. Biomed Pap Med Fac Univ Palacky Olomouc Czech Repub 2012; 156 (1):41-7. [CrossRef] [PubMed]

22. Schasfoort F, Pangalila R, Sneekes E, Catsman C, Becher J, Horemans $\mathrm{H}$, et al. Intramuscular botulinum toxin prior to comprehensive rehabilitation has no added value for improving motor impairments, gait kinematics and goal attainment in walking children with spastic cerebral palsy. J Rehabil Med 2018;50(8): 732-42. [CrossRef] [PubMed]

23. van den Noort JC, Bar-On L, Aertbeliën E, Bonikowski M, Braendvik SM, Broström EW, et al. European consensus on the concepts and measurement of the pathophysiological neuromuscular responses to passive muscle stretch. Eur J Neurol 2017; 24(7):981e38. [CrossRef] [PubMed] 


\title{
UPOTREBA BOTULINUM TOKSINA A I NAREDNA REHABILITACIJA AMBULANTNA KOD DECE SA SPASTIČNOM CEREBRALNOM PARALIZOM - EFEKTI I DILEME
}

\author{
Hristina Čolović1, ${ }^{2}$, Vesna Živkovići ${ }^{1,2}$, Dragan Zlatanović1, ${ }^{2}$, Nadica Milošević-Milenović3, \\ Dragana Janošević-Radović 4,5
}

\footnotetext{
${ }^{1}$ Univerzitet u Nišu, Medicinski fakultet, Katedra za fizikalnu medicinu i rehabilitaciju, Niš, Srbija ${ }^{2}$ Klinika za fizikalnu medicinu i rehabilitaciju, Klinički centar Niš, Niš, Srbija

${ }^{3}$ Dom zdravlja "Hipokrat Group" Niš, Niš, Srbija

${ }^{4}$ Univerzitet u Nišu, Medicinski fakultet, Katedra za ginekologiju sa akušerstvom, Niš, Srbija

${ }^{5}$ Klinika za ginekologiju i akušerstvo, Klinički centar Niš, Niš, Srbija
}

Kontakt: Hristina Čolović

Branka Krsmanovića 17/34, 18000 Niš, Srbija

E-mail: hristinamc@yahoo.com,

hristina.colovic@medfak.ni.ac.rs

Cerebralna paraliza (CP) po definiciji obuhvata grupu trajnih razvojnih poremećaja pokreta i držanja, koji uzrokuju ograničenje aktivnosti, a uslovljeni su neprogresivnom lezijom mozga u razvoju fetusa ili novorođenčeta. Najzastupljeniji tip je spastična cerebralna paraliza (SCP). Jedan od primarnih ciljeva lečenja dece sa SCP je omogućavanje aktivacija, promovisanje efikasnog kretanja, sprečavanje nastanka deformiteta koštano-zglobnog sistema i smanjenje bola. Deformiteti ekstremiteta predstavljaju najuočljiviju karakteristiku dece obolele od SCP, koja ih u velikoj meri ograničava u aktivnostima svakodnevnog života. Smanjenje spasticiteta i prevencija kontraktura, uz mogućnost pune aktivacije i odlaganje hiruške intervencije, uslovila je pravu ekspanziju primene botulinskog toksina tipa A (BTA) u terapiji dece sa CP poslednjih godina. Poznat kao najjači neurotoksin u prirodi, BTA nakon aplikacije smanjuje spazam ireverzibilnom denervacijom u nivou neuromišićne spojnice, dok je funkcionalni efekat vremenski ograničen. $U$ tom vremenskom periodu neophodno je proceniti funkcijski motorički status deteta, jasno i realno definisati ciljeve u saradnji sa roditeljima i primeniti adekvatan rehabilitacioni protokol. Internacionalni konsenzus 2010 god. definisao je prokolol, doze, mesto aplikacije, rehabilitacioni protokol. Nakon dvoipodecenijske primene, pored ostalih, javile su se i dileme u pogledu efekta rehabilitacije nakon primene BTA.

Acta Medica Medianae 2020;59(1):110-115.

KIjučne reči: cerebralna paraliza, deca, botulinum toksin tip A, spasticitet, rehabilitacija 